\title{
On Matters Evidential: A Reply
}

To Professor Uldricks's radically dissenting comment I will respond at the end. Professors Kennan, Gillette, and Dallin have raised an array of thought-provoking particular points. Since my allotted space is far too short for full reply, I will, like the peasant who yelled "Help!" over Moscow radio, focus on what seems most essential.

I agree with Professor Kennan that the Bolshevik Revolution came into the world breathing fire against bourgeois regimes, but I also stand by the statement that it had to fight for its life; and wonder if the Western governments' response to the Revolution would have been much different had the Bolsheviks muffled their hostility toward them. On the ambiguity about war, I tried to summarize the Leninist view that the approaching unavoidable intercapitalist war, supposedly generated by imperialism, would, given the USSR's revolutionarily provocative essence, turn into an anti-Soviet war, which hence appeared derivatively unavoidable. Regarding Stalin's gamble on the Nazis, when I consider how terribly dangerous Germany and the world looked to him at around 1932, and how very grave the internal Soviet situation was, it seems to me that he would have been willing to take his chances with a less than fully subservient German Communist regime in preference to the other possible German outcomes if it were conceivable (as it was not) that German communism could take and consolidate power without this causing an international crisis threatening to involve the USSR in an early war. As for oppositional tendencies, the German party's conduct in 1932-33 would suggest that Stalin's influence was securely dominant.

Professor Gillette's reformulation and extension of my argument are interesting, to me especially for his discussion of Far Eastern policy. I do agree that the "purposive" interpretation of Stalin's policy takes on explanatory potency only at the point where his individual capacity to determine the policy grows greater than it was in the mid-1920s. As to whether Trotsky and Bukharin might, if in power, have adopted the German policy that Stalin followed in the early 1930s, my sense of them as political personalities, and my reading of their published thoughts and lives, persuades me that they would not have; that both, being among the strongly anti-Fascist Communists, would have opted for earlier adoption of the very democratic-front line that Trotsky urged in his prescient articles before the Nazis took power. This is not to argue that Stalin was proFascist, but only that, as the exponent of a Russian variety of "National Bolshevism," he could envisage and seek-in a way Communists of strong anti-Fascist tendency could not-a tie of mutual convenience with a brutally revolutionarynationalist force like German National Socialism.

This matter of diversity of political personalities shows how important the issue raised by Professor Dallin concerning Stalin's Russian nationalism is: Was it "manipulative" or "genuine"? Did it, as he affirms, graduate from being "instrumental" to being "internalized"? The view I expounded in Stalin As Revolutionary, with supporting evidence that seemed persuasive, is that the Russian 
nationalism, or the seeds of it, sprouted (as "genuine") way back when young Dzhugashvili found a Russian revolutionary identity-figure in Lenin; and that it subsequently developed as both "genuine" and "instrumental."1 More evidence will come out in the not too distant future in the sequel, Stalin and the Revolution Above. Here I can only say that it is an evidential matter, and that Professor Dallin's thesis (first "instrumental," then "internalized") is just as much in need of supporting evidence as any other.

On proneness to perceive historical parallels, I agree that this was not unique with Stalin and indeed that it is a general human trait-which Stalin possessed in unusually pronounced form. On December 1933 as the turning point toward the "popular front" policy, I would, again, like to know the evidence for Professor Dallin's suggested (but not explicitly stated) view that Stalin switched at that point, especially as his early 1934 party congress speech gives no sign that he had been persuaded as yet by the Litvinovs, hard as they must have been trying.

It is curious to read Professor Uldricks's statement that all such attempts as mine to "revise the traditional picture" of Soviet foreign policy (I do plead guilty to such revisionism) "founder on the lack of evidence." Curious, because a tendency to be cavalier about evidence is so noticeable in his comment. If all attempts at my kind of revisionism must founder on lack of evidence, one would have expected Professor Uldricks to expose my argumentation's evidential inadequacy. Instead, he as it.were writes his own article, with frequent criticisms of me for differing. Unfortunately, I have little space in which to deal with his piece as he failed to deal with mine. But briefly, and first on matters of evidence:

(1) He writes that "there is no evidence to show" that Stalin "knowingly" followed the policy that led to the KPD's destruction and consolidation of "a thoroughly totalitarian, militarily powerful Nazi regime." This makes my argument considerably balder than it was (what I argued was "He forced upon the KPD a policy that abetted the Nazi victory"), for Stalin could hardly have known in advance just how "totalitarian," and so forth, the Nazi regime would be. But my essay presents evidence that Stalin consciously adopted a policy that abetted the Nazi victory, for example, Stalin's statement to Heinz Neumann and Zinoviev's 1933 private testimony. This and other adduced evidence may not be persuasive, but is it "no evidence"?

(2) "It is certainly true that Stalin, along with most Soviet leaders, feared war in 1927 and later." This refers to the war scare, disregarding the evidence adduced in my essay that the expectation of war was rooted in Lenin's analysis of imperialism, and that Stalin in a 1925 speech, kept secret at that time, expressed his personal preview of an oncoming major war which the USSR would enter at a moment of its choosing and to advance its purposes (that is, of revolutionary aggrandizement). Why disregard this evidence?

(3) My argument "fails to account for Soviet foreign and domestic policies" in the 1935-38 "popular front" period. Yet, it transpires that I do deal

1. A scholar who not long ago emigrated from Soviet Russia, Dr. Mikhail Agursky, has unearthed further evidence that Dzhugashvili gravitated at an early age toward a Russian nationalist outlook. See his article, "Dvulikii Stalin," Vremia $i m y$, no. 18 (June 1977), especially pp. 133-35. 
with the popular front policies: "Tucker contends that these Soviet approaches to the Western powers were merely ruses designed to demonstrate to Hitler the importance of a Russo-German pact." Evidence? My 1965 essay, "Stalin, Bukharin, and History As Conspiracy," where (Uldricks says in his footnote 4) "Tucker argues that Stalin never supported the collective security campaign which was supposedly adopted by the Politburo against his will." Evidence? Footnote 4 cites no particular page, but the statement in question is presumably the one just following my 1965 argument that the diplomacy of the 1939 pact was prefigured in Stalin's 1934 party congress speech: "But for some time Hitler showed no receptiveness to feelers from the East. In these circumstances Stalin was content to go along with the policies of the anti-fascist Popular Front and the diplomacy of collective security which Foreign Commissar Litvinov pursued vigorously in the middle 1930s." I submit that this position. which I still hold, is not correctly represented in either of Professor Uldricks's above-quoted statements.

(4) Is it true that "the student of Soviet foreign policy in the 1930s has rather little evidence with which to work," or "has at his disposal only the public record of Soviet diplomatic activity, as well as his own logical reconstruction ..."? No, in addition he has Stalin's published views, the Soviet press for those years, the Nazi archives as well as U.S. and British published records, the testimony of foreign observers and knowledgeable foreign Communists who survived, a large post-Stalin memoir literature. both official and samizdat, Khrushchev's recorded memories, and so forth. Far from all one would like, but still-the bits and pieces from which history is reconstructed.

To illustrate with a bit that bears importantly on my argument about Stalin's German policy of 1932-34: in a document that has just appeared, a surviving Soviet foreign office official of the 1930s, Evgenii Gnedin, reveals, on the basis of research in the German foreign policy documents, that the German diplomat von Dirksen paid a special unofficial visit to Molotov in Moscow on October 29, 1933, just one day after Litvinov left Moscow for Washington to see Roosevelt. Mr. Gnedin concludes that "these steps of Molotov were carried out deliberately and with the knowledge of fascist diplomacy, secretly, behind Litvinov's back. . .." Thereby, he states, "the ground was prepared for rapprochement with Hitlerite Germany at the very time when it had openly turned to preparing war in Europe."3

In conclusion, three points relating to Professor Uldricks's modes of reasoning:

The policy I ascribe to Stalin is "altogether different from the traditional Bolshevik approach to Germany as well as to the capitalist state system as a

2. "Stalin, Bukharin, and History as Conspiracy" has been reprinted in Robert C. Tucker, The Soviet Political Mind: Stalinism and Post-Stalin Change, 2nd ed. (New York, 1971), where the statement quoted here appears on page 74 .

3. E. Gnedin, Iz istorii otnoshenii mezhdu SSSR $i$ fashistskoi Germaniei: Dokumenty i sovremennye kommentarii (New York: Khronika Press, 1977), p. 13. Mr. Gnedin, who headed the Narkomindel's press section and was personally friendly with Litvinov, was arrested shortly after Litvinov's dismissal in 1939 and spent many years in camps and exile. He now resides in Moscow. 
whole: Leninist tactics called for the exploitation of rivalries among the imperialist states in order to divide them, but not for the provocation of major wars between the great powers." Not "altogether" different (for exploitation of rivalries remained central with Stalin), yet different. But the manifest intention of my essay was to bring out what was innovative in Stalin's foreign policy as well as what had roots in Leninism.

Professor Uldricks disagrees with my interpretation of Stalin's phrase "socialist borderland" as referring to countries girdling the USSR, especially East European ones: "It seems logical, however, to construe Stalin's words in quite a different way. . . Would the addition of Rumania or even Poland to the Soviet camp guarantee the USSR against external danger? No." (But what if we add the Baltic republics, Bulgaria, Hungary, parts of Finland and Czechoslovakia, East Prussia?). Hence, "It seems more likely that . . Stalin meant the addition of one or more industrially developed powers to the socialist commonwealth." No such country then girdled the USSR. So, why "borderland"?

For Professor Uldricks a key thing about Stalin in foreign policy is that he was "cautious," not a gambler. This is a light reed on which to float a heavy interpretation. Caution and gambling are not mutually exclusive. Some people are cautious gamblers. Some hypercautious people make gambles at certain times that are far more reckless than they recognize beforehand-as Stalin did with Hitler. 